\title{
Operation and Significance of Supply Chain Management (SCM) in Business
}

\author{
Rohit Vikas Akole \\ DOI: 10.29322/IJSRP.11.06.2021.p11403 \\ http://dx.doi.org/10.29322/IJSRP.11.06.2021.p11403
}

\begin{abstract}
Purpose: This paper shows the working of Supply Chain Management. Also, it gives the processes which happens in the supply chain industry.

Methodology: This paper gives the hypothesis of process of supply chain management and gives whatever advanced changes made in the industry.

Findings: This paper states, how time and transportation are basic pieces of SCM industry and how it is related to procedures inside. Also, this paper shows how raw material is also important in the process.

Research implications: The research in the paper focus on the information about quality of the product, inventory management, and how to deliver the product to the end user in time. This all applications holds a lot of weightage in the supply chain industry.

Practical implications: This model is utilized to do the item conveyance to the consumers everywhere throughout the world in excellent condition and in the stipulated time traverse.

This model is used to imply for supply chain management all over the world. It gives guidelines to deliver product in time.

Originality/value: This paper gives an idea of transferring the product to their exact location and it gives the process of supply chain.
\end{abstract}

Index Terms- Logistics, Management, Network, Supply Chain, Transport network.

\section{INTRODUCTION}

There is growing literature on supply chain management theory in marketing (Aksoy, 2000; Bharath, 2010; Donohue \& Croson, 2002; H. Ittmann, 2003; H. W. Ittmann \& Nichols, 1999; Johnson, 2006; Larson \& Rogers, 1998; Rogers \& Leuschner, 2004; Swami \& Shah, 2013; Woodruff, 2004). This article describes the economist' interests in transportation field as this article is about the supply chain management. Because of the involvement of a lot of money in the field of transportation, economists consider this topic with a lot of interest. This article also consider it important to add this topic in the academic syllabus with the evolution which started from the start of the world war (Farris, 1997). This article talks about 'Horizontal Cooperation'. There is not much information gathered on this term. Horizontal Co-operation helps to reduce the price of transportation and stock to increase profit and work efficiently. In Horizontal Co-operation, different firms with the same transport activities should connect to each other and do the work together in order to reduce the cost and make it efficient and it also makes work easy (Cruijssen, Dullaert, \& Fleuren, 2007). Less research has been done on dependability of the supply chain. More research should be done on this topic. As supply chain plays a significant role in the organization, they should know how much they should be dependable on the supply chain. The paper gives the models and theories about the above topic. In supply chain, company should deal with the most common cause of failure, failure with supplier and distributor (Chen, Sun, $\mathrm{Hu}, \& \mathrm{Hu}, 2015)$. This paper describes the effects of supply chain management in the chemical firms because of the time span of delivery. Delivery can be late because of following four factors. The hopper cars take more time than it expected, due to change in climate, bad road conditions, changing the mode of transportation at every place, particularly if there should be an occurrence of worldwide transportation devours for time and separation than single bearers. It additionally reveals to us how expenses can be diminished in the event that we evade and deal with a couple of things amid travel of products (Closs, Keller, \& Mollenkopf, 2003). Electronic trade is broadly utilized nowadays to sell distinctive items. Agri-food organization additionally utilizes it. This opens wide decision for purchasers and they can decide for best suppliers from everywhere throughout the world. Subsequently, article illuminates about the impacts of web-based business on today's supply chain enterprises. The significance of data innovation in the supply chain has purchased radical change to this market (Buhr, 2000). The opposition is developing step by step in each field. Because of the ascent in worldwide spending plan and rivalry, the need to choose best providers is likewise developing. The article clarifies the FP-development calculation that is utilized for picking aggressive suppliers from everywhere throughout the world (Lin, 2009).

\section{RESEARCH METHOD}

This paper fundamentally gives a detail clarification of strategies utilized by "HP" in their supply chain. This strategy is utilized to quick track the benefits particularly by upgrading stock and in this manner diminishing stock expenses (Billington et al., 2004). The supply chain is also used for the international trades. There are several factors which need to be considered as the international trade varies from country to country. Their way of communication, culture, trade methods and their unity these all factors may or may not be like ours. So, in these situations, all these factors need to be considered. Companies which acts according to these factors to deal with those countries helps to improve the performance of the company (Griffith \& Myers, 2005). The competition is increasing continuously in every field due to globalization. The social contrasts i.e., the distinctive work technique, demeanours, considering, new creations, and so forth prompts social astuteness inside the association and outside. It decreases the time for delivering the product in supply chain industry (Hult, Ketchen, \& Nichols, 2002). 


\section{SUPPLY CHAIN MANAGEMENT}

For the purpose of providing the customer with the benefit, supply chain management is the activity which is wired within the firm (Larson \& Rogers, 1998). The author states that Supply chain management is used to get a reasonable advantage in competition by including supply chain activities (H. W. Ittmann \& Nichols, 1999). Supply chain management includes various activities like purchasing, materials handling, production planning and control, warehousing, logistics, inventory management, distribution, delivery, and vendor management and its primary goals cost reduction, service improvement, improved communication and interaction among supply-chain partners, and increased flexibility in terms of delivery and response times (Ranganathan, Dhaliwal, \& Teo, 2004). The author states that SCM is the process of planning, implementing, and controlling the operations of the supply chain to fulfil the customer demand more efficiently. It is spread in all movement and storage of raw materials, work-in-process inventory, and finished goods from start of the product till the end of the consumption of the product (Chandra et al., 2013). Supply chain management performs a vital role for 2 causes. First, it deals with the resources which are used for manufacturing of goods and services. Second, Buying activities affect supplier's ability to provide material (Wolf, 2011). Supply chain management efficiently includes suppliers, manufacturers, warehouses, and stores to produce goods in right quantity, at right time, and at the right place. It helps in reducing costs (Mak \& Ramaprasad, 2003).

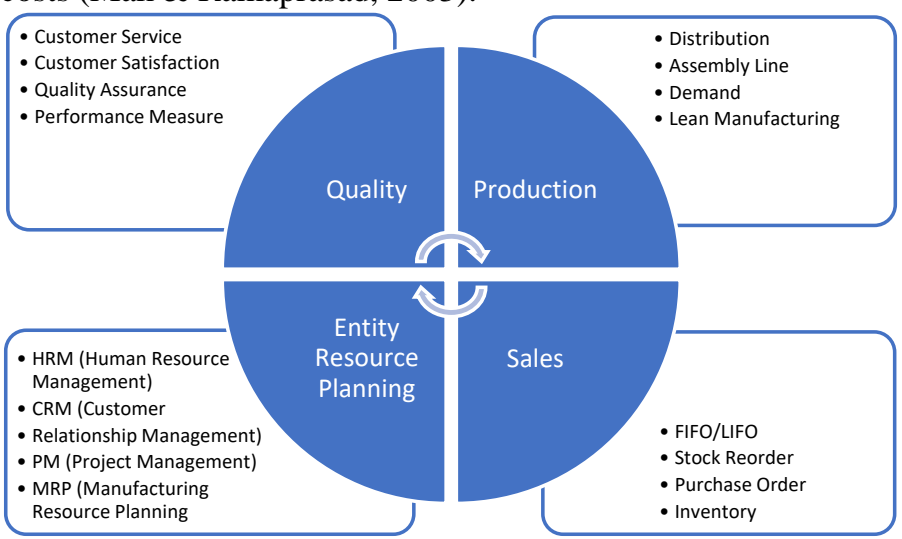

Figure 1: Supply Chain Management Model

\section{A. Quality}

Author said in this statement that, better quality gives us a sense of satisfaction and pleasure and we can feel it (Milne, 1933). Quality is made of marketing, engineering, manufacturing and maintenance, these are the vital factors in improving the services to the customer (Seawright \& Young, 1996). The definition of quality is varied per the host i.e. for the customer, quality means the durability of the product, for manufacturer quality means the consistency of goods and deliveries and for the supplier quality is defined as timely payment for his goods (Gehani, 1993). The quality is defined per the valuation of the goods, the higher the value the better quality of goods (Khandelwal, 2010). The harmony of the design of the product and the resulted product is said to be the quality of that product (Banker, Khosla, \& Sinha, 1998). Quality In manufacturing is defined by the execution of the product's performance whereas in the marketing and economics literature quality is defined by the rank of the product based on its performance (Karmarkar \& Pitbladdo, 1997).

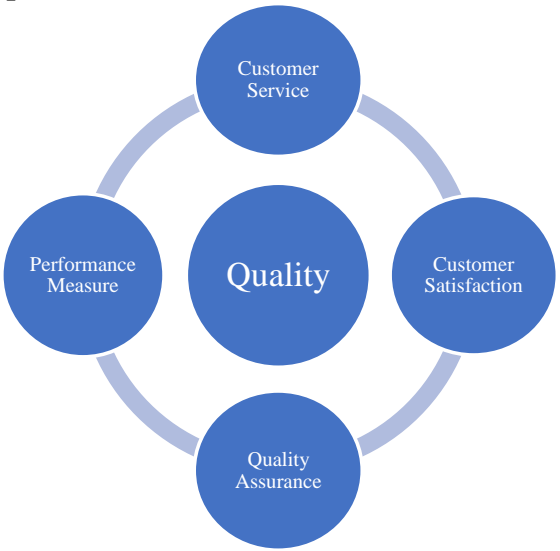

Figure 2: Quality Model

\section{a. Customer Service}

The author conveys in this statement that, providing service to the customer is a type of managerial strategy which is there for doing things as per the customers wish. By satisfying the consumers the author believes that the company will achieve the objectives and goals easily. Because of this, companies design processes by knowing, understanding and concentrating on customers need (Wagenheim \& Reurink, 1991). The author distinguishes the difference between the internal and external customer service. Which includes the customers who are not the part of the organization. Whereas the internal customers are the one who is involved in the internal affairs (L. A. Martin \& Fraser, 2002).

\section{b. Customer Satisfaction}

Author states the definition of the customer satisfaction. Which is given by the increment of the experience due to the single or multiple transactions. Also, it determines the maximum price the customer is ready to pay for the given product and determine their threshold (Anderson, 1996). Furthermore, the customer satisfaction is also useful in understanding the quantity and the quality of the customer. Furthermore, the increasing customers are viewed as the country's economic health. Also, to most of the firms the customers are viewed as the most important assets to the company. which I agree to (Tuli \& Bharadwaj, 2009).

\section{c. Quality Assurance}

The author states that the quality can be improved and it can be protected but we can't promise for it. The quality assurance is the monitoring and evaluating the quality but unfortunately, they don't know the methods of monitoring the quality in the United States of America (Welch \& Grover, 1991). The author states that the quality is not an internal function but it is from the outer side. Quality represents the value of the manufacturer in the market. The incremental audit as a better example to the quality assurance (Lessinger, 1976).

\section{d. Performance Measure}

The authors describe in the statement that the measures should be in the control of the user in the aspect of the performance. The performance is calculated based on the group of customers that go to make up the measure. But there are some aspects of performance measures which are not in control of the users. (Hurst, 1980). The author emphasizes on the critical issue of the 
theory, which underlines the choosing of the quantity of incentive to give away. As author states, in incentive contracts, goals can be achieved by adding some more performance measures in the existing measures (Baker, 1992).

\section{B. Production}

The author's citations of the definition of the production, the vital parameter which affects the production system execution is reordering (Biggs, Li, \& Rogers, 1998). The three important parameters in the production system are distribution planning, inventory control and production control (Swami \& Shah, 2013). To effectively use the production resources the manufacturers could use the short interval scheduling algorithms to schedule the production based on the demand (Stenger, 2011). The most satisfactory approach for the production is selective information sharing, full information sharing and no information sharing (Huang \& Iravani, 2005). Production for the supply chain members depends upon the deliveries from the manufacturer (Morash \& Clinton, 1997). The process of production and distribution is dependable as well as continuous (Swaminathan \& Tayur, 2003).

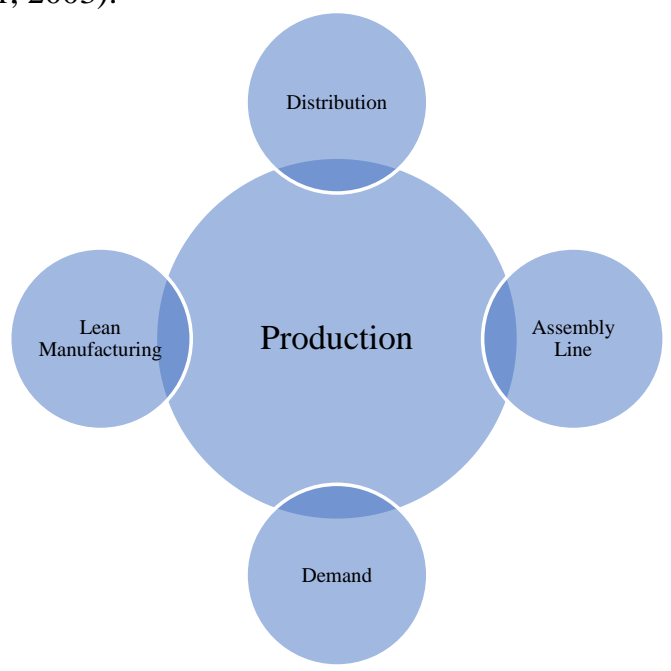

Figure 3: Production Model

\section{a. Distribution}

I agree with the author's statement describing the distribution of the product, which according to him should be done by the company itself by hiring the importer so that the importer will not be misguided (Miller \& Sogi, 1970). The author in here suggests that for the economies who had the greater success had the mass production and thus, the mass distribution which has to lead them to be successful (Lewis, 1930).

\section{b. Assembly Line}

The author brings out the key point for the assembly line. Here he positively supports the working of multiple assembly lines because they bring the best out of them by rationally scheduling them (Dong, Chen, \& Lu, 2015). The author states that the, even if the number of models of the assembly line is limited it is better to use or affordable to use the assembly line to cope up with the ever-increasing demands of the customers (Yano \& Rachamadugu, 1991).

\section{c. Demand}

I am in the agreement with the author's statement regarding the demands the authors plainly states that the demands of the customers are always unsatisfactorily met or not met at all. This is due to the alternative to the product offered by the organization is dependent on the profits increased by the company (Chandukala, Edwards, \& Allenby, 2011). the above para states that the due to the uncertain demand and the uncertain stability that the prices can change at any point of time with respect to the amount demanded (xe \& zquez, 1995).

\section{d. Lean Manufacturing}

I am with the agreement with the author who wants to convey a very simple yet sharp view. The author states that the whole purpose of the lean production is to fulfill the customer by providing him the highest quality, fewer costs as well as in the shortest time as possible.so to reach this definite goal the only way is to discard the waste (Dentz, Nahmens, \& Mullens, 2009). The concise meaning of the author's formulation was that the lean production is the outcome of the hard or and the experience of decades based on the company in the japan, where it culminates the positive aspects of the craft and the mass production. Simultaneously trying to avoid the excessive costs of the former and the sturdiness of the latter. Furthermore, it is believed that the lean manufacturing uses all the assists in less quantity such as half the human work, manufacturing space, investment tools, engineering hours and the hours to develop the new product is also halved (Hummels \& de Leede, 2000).

\section{Sales}

The author conveys that sales are but the transaction in goods whether it may be a moveable property or a bond, where bond means a future trade of goods (J. S. Martin, 2012). Further production of the goods depends upon the past history of the sales of the goods (Ho, Chi, \& Tai, 2005). Sales occur due to the unpredictable demand and the fundamental demand of the customer which determines the peaks and valleys for the product's sales (Vokurka \& Lummus, 1998). The manufactures performance depends upon the advancement of the sales additionally the scan backs are also crucial to predict the sales (Lee, Padmanabhan, \& Whang, 2004). To receive more earnings, sales play the important role (Good, 1993). Intelligent decisions and precise plan of execution lead to the upgradations of the sales (Plank \& Reid, 1994).

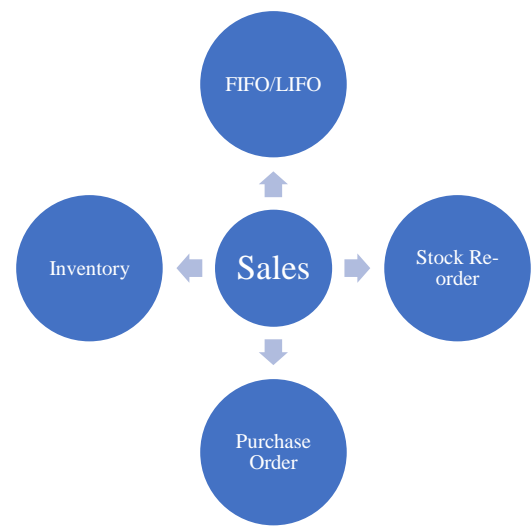

Figure 4: Sales Model

\section{a. FIFO/LIFO}

I am in the agreement of the authors wording, regarding the examining of the reactions of the investors to a firm's policies of the first in first out and last in first out. So, these different types 
of accounting change have reached many and have made the researcher work on them (Hughes \& Schwartz, 1988). The above texts reflect that the method of the first in first out and last in first out requires the consideration of the several factors in which the potential tax effect of the accounting method is also as much as important (Sunder, 1976).

\section{b. Stock Reorder}

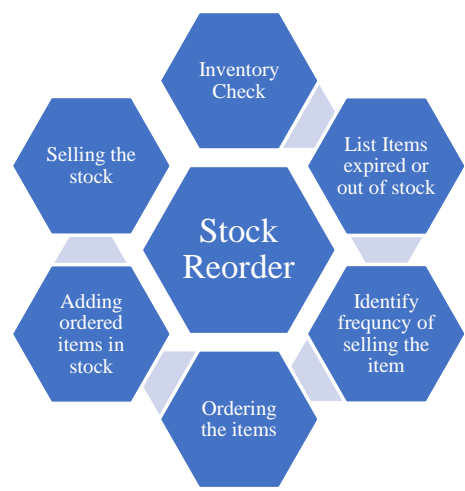

Figure 5: Stock Reorder Cycle

The inventory is kept to preserve or stock up the commodity or goods but they have limitations as to the expiry of the items, which cannot be stored further into the future (Shen, Dessouky, \& Ordonez, 2011). As the author states that there were times when the stock was not up-to-date and that there was no information regarding it stored into the servers so as the author says that there was no virtual inventory as such (Lingaraj, Balasubramanian, \& Krishnamurthy, 1983).

\section{c. Purchase Order}

I am in the complete agreement with the author's viewpoint. It is better to use the correct signs when and where they are necessary because they will lessen the confusion for the person who will review the documents later (Indusi, 1997). The author here tries to explain the importance of the advance order. From many years, the customers have been placing the advance order deals before the organization and pre-booking the commodity. This helps the organization to grow (Moe \& Fader, 2002).

\section{d. Inventory}

I agree with the author's remarks regarding the inventory policy. Here the author tries to explain that we must first look out for the availability of the inventory policy if there is any. If there is no inventory policy then we might just waste our time in doing so (Sun, 2004). The author says that the inventory model of data and pal3 presented us with the unique model which is dependent on the instantaneous inventory level. In explaining this aspect, they developed a model in which the inventory and the profit functions, and brings forth the final rule of the optimal order quantity (Urban, 1992).

\section{Entity Resource Planning (ERP)}

Entity resource planning system is a peculiar type of software in which all sorts of information related to the supply chain are stored and that information is made available to the organization (Ragowsky \& Somers, 2002). The ERP enclose a wide-ranging software from supporting day-to-day business operations to decision making (Hitt, Wu, \& Zhou, 2002). ERP helps to integrate all the existing information under one roof and provide the information across the entire firm (Gattiker \& Goodhue, 2005). These ERP can remarkably alter the job and business

This publication is licensed under Creative Commons Attribution CC BY. processes and it could vary per the implementation stages (Morris \& Venkatesh, 2010). ERP is a pivotal element in the entire system the future of the company is dependent mostly on this factor (Ahn \& Choi, 2008). The dateless dream of integrating all the information on a single system has been possible because of the ERP (Wang, Klein, \& Jiang, 2006).

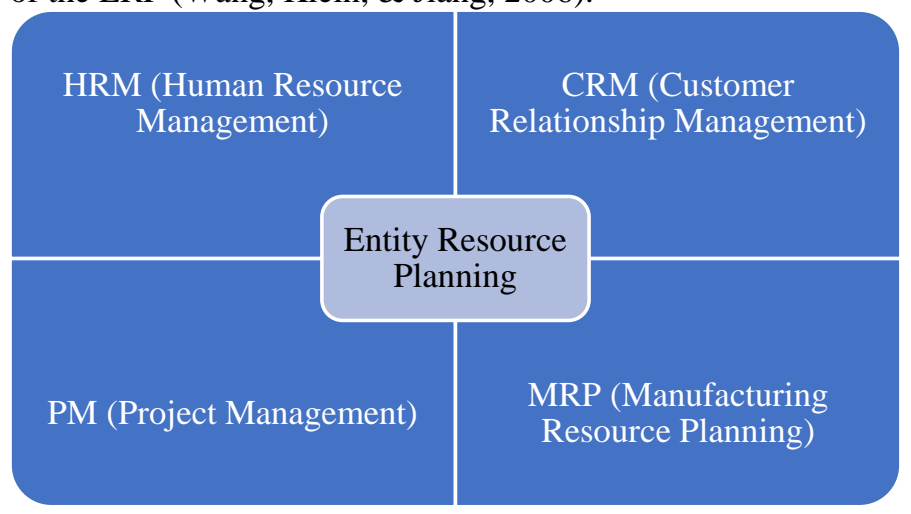

Figure 6: Entity Resource Planning Model

\section{a. Human Resource Management (HRM)}

I am in good agreement with the author's verbalization of the thoughts regarding the human resource planning. The HRP works its best to put up with the customers, they help in planning for the organizations the HRP also helps the organization to interpret the demands and the needs of the customers and suggest the new management schemes deal with it (Nkomo, 1987). The author describes the HRP as the best way to approach the information handling as well as planning system. Furthermore, he says that the public sector was unaware of the benefits of the HRP but they are now becoming aware. The HRP is working very fine in the private sector as well (Sword \& Cutsinger, 1984).

\section{b. Customer Relationship Management (CRM)}

I agree with the statement of the author. The CRM helps in realizing the relationship between the organization and the customers leading to the better productivity of the organization by effectively analyzing the customers' needs and the evergrowing demands (Zaablah, Bellenger, \& Johnston, 2004). So here the verbalization of the author's thoughts means that the interaction between the customer and the organizations helps in deciding the future of the company. This is done by analyzing that the customers' demands and forming the required strategies uniquely made to fulfill the customers' needs (Kamakura et al., 2005).

\section{c. Project Management (PM)}

I am in accordance with the author's statement. Where he says positively about the project management being the widely successfully used methodology for planning, monitoring as well as controlling simple as well as the complex task at the same time (Kolisch, 1999). The author says that the project management is nothing other than the reexamination of the assumptions in the functional organization which provides the healthy environment when the managers and the professional employees meet (Butler, 1973).

\section{d. Manufacturing Resource Planning (MRP)}

I am in total agreement with the author's opinions. MRP uses various resources from the integrated information system which includes the bill of material into its components and the raw 
materials (J. F. Cox \& Clark, 1984). The author states that the optimum and the accurate production and financial data are provided by the MRP. So basically, it's the looping system in which the financial data are related to the operation data and so on and they determine the surety of the production costs by using the what If capabilities which perform the integrated simulation of the product in requirements, output, related costs and so on (Polonenko, 1999).

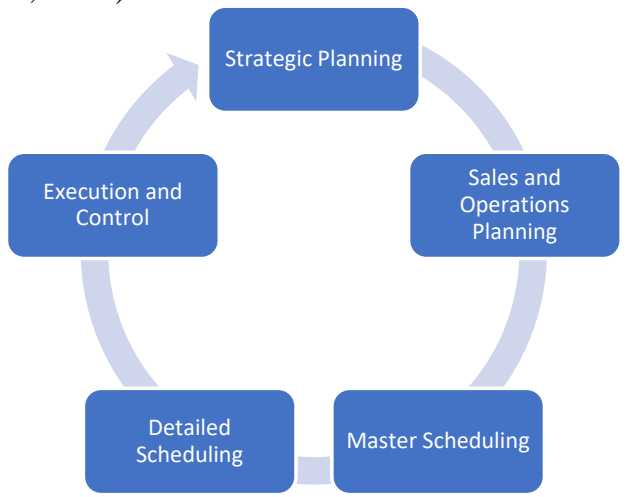

Figure 7: Manufacturing Resource Planning Model

\section{Discuss Research}

The examination informs us concerning a detail contemplate in the field of supply chain and how essential it is for associations. It additionally reveals to us its scholarly development and how they deal with the without a moment to spare conveyance and assembling. Supply implies the organization chooses to make items and get them in the market for the buyers. If there should arise an occurrence of interest, the client inclination is most essential and market study is done. At that point, appropriately the item is produced. Request and supply both are essential calculations at the time of manufacturing the product (Zinszer, 1996). To convey items in excellent condition and inside time is an essential component. To do this, the transportation framework must be exceptionally proficient and consistent in their administration. Great and long separation conveyance prompts higher expenses. The organization needs to effectively oversee cost and time to meet client necessities (Smith, 2008). In SCM, harmonization between each procedure is basic. From keeping up the stocks to the definite conveyance of item, every progression and each asset like provider, retailer, and so on are to keep up their quality and standard to pick up consumer loyalty. The client is the fundamental piece of SCM, so more inclination is given to their request (Niraj, Gupta, \& Narasimhan, 2001).

\section{Results}

The idea of supply chain administration (SCM) helps the organizations in this condition to accomplish powerful undertaking coordination. In the writing, there are various papers managing the ideas and techniques of SCM. Be that as it may, there is a requirement for displaying of supply chain conditions with the target of measuring the execution of different procedures, techniques, and innovations. For this, the use of operational research strategies can be utilized (Gunasekaren, Macbeth, \& Lamming, 2000). Hypothetically, higher edges give more grounded motivations to maintain a notoriety for high caliber, and they urge firms to expand item quality so as to take business from opponents (Dana \& Fong, 2011). Production is

This publication is licensed under Creative Commons Attribution CC BY. making the objects using the compounds and different processes and various technology advancements (Grinyer \& Tiefenbrun, 2006). The sale model consists two aspects of growth. Direct growth and Indirect growth, where direct growth is based on the sales in general. But in indirect growth, it compares sales of two same genre product with each other (Stojanovi, x, \& Dragi, 1988). Entity Resource Planning is for three job features, skill variety, autonomy, and feedback. ERP System gives a way to change the well-established relations in the organizations which are technology-aided organizations to change the condition (Morris \& Venkatesh, 2010).

\section{Contribution and New Insight}

It is important to plan in advanced for the upcoming research and evolution in the supply chain management. Even after that, there are flaws in the supply chain and those has to be solved in the future (Stadtler, 2005). Earning profit from providing the service is the main objective of the company. For earning profit in the supply chain, proper management of the resources should be there. The more efficiently you manage the resources the more profit you will be getting from the supply chain process. Company should do the waste management to save cost on the raw materials which they pay extra for no reason where the work can be done more efficiently. Also, company should look for the profits of shareholders and the company too. For instance, Toyota has done an excellent job with time management, they produce the product and delivers the product accurately on time. Toyota follows the just-in-time strategy strictly (A. Cox, 1999). Every company's basic goal is to manage their production and to manage their inventory efficiently. Providing product in the market or delivering the product to the end user in good condition, fair value, and in time, these are the basic goals of the company or industry. For achieving these goals, it is important to study and improve supply chain management in industry (Harland, 2013).

\section{Conclusion}

It is very important to understand the in-depth insight about the company or industry and the supply chain management to fulfil the need of end user and the market. Without sufficient knowledge about the management, we cannot create an efficient management plan. Also, designing the model for the management is necessary. With efficient plan and model, it gets easy to deliver products in time and in low costs. All people who are concerning to the industry i.e., Manufacturer, retailer, distributor, etc. consist in the supply chain. Without the loyalty and quality of work, the supply chain cannot be managed efficiently. Also, doing everything in time i.e. Just-in-time strategy should be there in the organization along with the other crucial factors in order to run supply chain successfully in the organization. Nowadays, environmental factors and social factors are also considered by the company or organization. Improving quality of services is also considered as an important aspect to increase the sales.

\section{References}

[1] Ahn, B. S., \& Choi, S. H. (2008). ERP System Selection Using a Simulation-Based AHP Approach: A Case of Korean Homeshopping Company. The Journal of the Operational Research Society, 59(3), 322-330.

[2] Aksoy, Y. (2000). Introduction: Observations on Supply-Chain Management. Interfaces, 30(4), 1-2. 
[3] Anderson, E. W. (1996). Customer Satisfaction and Price Tolerance. Marketing Letters, 7(3), 265-274.

[4] Baker, G. P. (1992). Incentive Contracts and Performance Measurement. Journal of Political Economy, 100(3), 598-614.

[5] Banker, R. D., Khosla, I., \& Sinha, K. K. (1998). Quality and Competition. Management Science, 44(9), 1179-1192.

[6] Bharath, R. (2010). [Supply Chain Management: An Introduction to Logistics (Paperback), D Waters]. The Journal of the Operational Research Society, 61(9), 1432-1432.

[7] Biggs, J. R., Li, E. Y., \& Rogers, J. C. (1998). The Effects of Back Ordering on Performance: Marketing and Production Cooperation in Supply Chain Management. Journal of Marketing Theory and Practice, 6(4), 26-40.

[8] Billington, C., Callioni, G., Crane, B., Ruark, J. D., Rapp, J. U., White, T., \& Willems, S. P. (2004). Accelerating the Profitability of Hewlett-Packard's Supply Chains. Interfaces, 34(1), 59-72.

[9] Buhr, B. L. (2000). Information Technology and Changing Supply Chain Behavior: Discussion. American Journal of Agricultural Economics, 82(5), 1130-1132.

[10] Butler, A. G. (1973). Project Management: A Study in Organizational Conflict. The Academy of Management Journal, 16(1), 84-101. doi: 10.2307/255045

[11] Chandra, H. E. M., Rinkoo, A. V., Verma, J. K., Verma, S., Kapoor, R., \& Sharma, R. K. (2013). SUPPLY CHAIN MANAGEMENT WITH COST-CONTAINMENT \& FINANCIALSUSTAINABILITY IN A TERTIARY CARE HOSPITAL. Journal of Health and Human Services Administration, 36(1), 3-23.

[12] Chandukala, S. R., Edwards, Y. D., \& Allenby, G. M. (2011) Identifying Unmet Demand. Marketing Science, 30(1), 61-73.

[13] Chen, G., Sun, X., Hu, H., \& Hu, Y. (2015). Research on Modeling and Algorithm of Supply Chain's Reliability Based on CCFSM. Journal of Coastal Research, 99-103.

[14] Closs, D. J., Keller, S. B., \& Mollenkopf, D. A. (2003). Chemical Rail Transport: The Benefits of Reliability. Transportation Journal, 42(3), 17-30.

[15] Cox, A. (1999). Power, value and supply chain management. Supply Chain Management: An International Journal, 4(4), 167-175.

[16] Cox, J. F., \& Clark, S. J. (1984). Problems in Implementing and Operating a Manufacturing Resource Planning Information System. Journal of Management Information Systems, 1(1), 81-101.

[17] Cruijssen, F., Dullaert, W., \& Fleuren, H. (2007). Horizontal Cooperation in Transport and Logistics: A Literature Review. Transportation Journal, 46(3), 22-39.

[18] Dana, J. D., \& Fong, Y.-F. (2011). PRODUCT QUALITY, REPUTATION, AND MARKET STRUCTURE. International Economic Review, 52(4), 1059-1076.

[19] Dentz, J., Nahmens, I., \& Mullens, M. (2009). Applying Lean Production in Factory Homebuilding. Cityscape, 11(1), 81-104

[20] Dong, Q., Chen, S., \& Lu, J. (2015). Modeling and Optimization of Multi-Model Multiple Assembly Line Mixed-Line Assembling by Turns. Journal of Coastal Research, 763-770.

[21] Donohue, K., \& Croson, R. (2002). Experimental Economics and Supply-Chain Management. Interfaces, 32(5), 74-82.

[22] Farris, M. T. (1997). Evolution of Academic Concerns with Transportation and Logistics. Transportation Journal, 37(1), 42-50.

[23] Gattiker, T. F., \& Goodhue, D. L. (2005). What Happens after ERP Implementation: Understanding the Impact of Interdependence and Differentiation on Plant-Level Outcomes. MIS Quarterly, 29(3), 559-585.

[24] Gehani, R. R. (1993). Quality Value-Chain: A Meta-Synthesis of Frontiers of Quality Movement. The Academy of Management Executive (1993-2005), 7(2), 29-42.

[25] Good, D. J. (1993). Managerial Coaching as a Sales Performance Moderator. Journal of Marketing Theory and Practice, 1(3), 74-83.

[26] Griffith, D. A., \& Myers, M. B. (2005). The Performance Implications of Strategic Fit of Relational Norm Governance Strategies in Global Supply Chain Relationships. Journal of International Business Studies, 36(3), 254-269.

[27] Grinyer, C., \& Tiefenbrun, I. (2006). Production values. RSA Journal, 153(5524), 28-31.

[28] Gunasekaren, A., Macbeth, D. K., \& Lamming, R. (2000). Modelling and Analysis of Supply Chain Management Systems: An Editorial Overview. The Journal of the Operational Research Society, 51(10), 1112-1115. doi: 10.2307/253923

[29] Harland, C. M. (2013). Supply chain management research impact: an evidence-based perspective. Supply Chain Management: An International Journal, 18(5), 483-496.
[30] Hitt, L. M., Wu, D. J., \& Zhou, X. (2002). Investment in Enterprise Resource Planning: Business Impact and Productivity Measures. Journal of Management Information Systems, 19(1), 71-98.

[31] Ho, C.-F., Chi, Y.-P., \& Tai, Y.-M. (2005). A Structural Approach to Measuring Uncertainty in Supply Chains. International Journal of Electronic Commerce, 9(3), 91-114.

[32] Huang, B., \& Iravani, S. M. R. (2005). Production Control Policies in Supply Chains with Selective-Information Sharing. Operations Research, 53(4), 662-674.

[33] Hughes, P. J., \& Schwartz, E. S. (1988). The LIFO/FIFO Choice: An Asymmetric Information Approach. Journal of Accounting Research, 26, 41-58. doi: 10.2307/2491178

[34] Hult, G. T. M., Ketchen, D. J., \& Nichols, E. L. (2002). An Examination of Cultural Competitiveness and Order Fulfillment Cycle Time within Supply Chains. The Academy of Management Journal, 45(3), 577-586. doi: 10.2307/3069382

[35] Hummels, H., \& de Leede, J. (2000). Teamwork and Morality: Comparing Lean Production and Sociotechnology. Journal of Business Ethics, 26(1), 75-88.

[36] Hurst, E. G. (1980). Attributes of Performance Measures. Public Productivity Review, 4(1), 43-49. doi: 10.2307/3380056

[37] Indusi, J. (1997). Creating a Purchase Order Using Spreadsheets. Mathematics Teaching in the Middle School, 2(6), 404-407.

[38] Ittmann, H. (2003). [Supply Chain Management Workbook, F. Harrison]. The Journal of the Operational Research Society, 54(10), 1114-1115.

[39] Ittmann, H. W., \& Nichols, E. L. (1999). [Introduction to Supply Chain Management, Robert B. Handfield, Ernest L. Nichols, Jr.]. Interfaces, 29(3), 111-114.

[40] Johnson, M. E. (2006). Supply Chain Management: Technology, Globalization, and Policy at a Crossroads. Interfaces, 36(3), 191193.

[41] Kamakura, W., Mela, C. F., Ansari, A., Bodapati, A., Fader, P., Iyengar, R., . . Wilcox, R. (2005). Choice Models and Customer Relationship Management. Marketing Letters, 16(3/4), 279-291.

[42] Karmarkar, U. S., \& Pitbladdo, R. C. (1997). Quality, Class, and Competition. Management Science, 43(1), 27-39.

[43] Khandelwal, A. (2010). The Long and Short (of) Quality Ladders The Review of Economic Studies, 77(4), 1450-1476.

[44] Kolisch, R. (1999). Resource Allocation Capabilities of Commercia Project Management Software Packages. Interfaces, 29(4), 19-31.

[45] Larson, P. D., \& Rogers, D. S. (1998). Supply Chain Management: Definition, Growth and Approaches. Journal of Marketing Theory and Practice, 6(4), 1-5.

[46] Lee, H. L., Padmanabhan, V., \& Whang, S. (2004). Comments on "Information Distortion in a Supply Chain: The Bullwhip Effect": The Bullwhip Effect: Reflections. Management Science, 50(12), 1887-1893.

[47] Lessinger, L. M. (1976). Quality Control and Quality Assurance in Education. Journal of Education Finance, 1(4), 503-515.

[48] Lewis, H. T. (1930). Distribution. The Annals of the American Academy of Political and Social Science, 149, 36-44.

[49] Lin, R. H. (2009). Potential Use of FP-Growth Algorithm for Identifying Competitive Suppliers in SCM. The Journal of the Operational Research Society, 60(8), 1135-1141.

[50] Lingaraj, B. P., Balasubramanian, R., \& Krishnamurthy, T. V. (1983). An Inventory Management and Materials Information System for Aircraft Production. Interfaces, 13(5), 65-70.

[51] Mak, K. T., \& Ramaprasad, A. (2003). Knowledge Supply Network. The Journal of the Operational Research Society, 54(2), 175-183.

[52] Martin, J. S. (2012). Sales. The Business Lawyer, 67(4), 1227-1243.

[53] Martin, L. A., \& Fraser, S. L. (2002). Customer Service Orientation in Managerial and Non-Managerial Employees: An Exploratory Study. Journal of Business and Psychology, 16(3), 477-484.

[54] Miller, M. I., \& Sogi, F. Y. (1970). Distribution. Antitrust Law Journal, 40(1), 29-39.

[55] Milne, J. A. (1933). QUALITY. Journal of the Royal Society of Arts, 82(4225), 2-12.

[56] Moe, W. W., \& Fader, P. S. (2002). Fast-Track Article: Using Advance Purchase Orders to Forecast New Product Sales. Marketing Science, 21(3), 347-364.

[57] Morash, E. A., \& Clinton, S. R. (1997). The Role of Transportation Capabilities in International Supply Chain Management. Transportation Journal, 36(3), 5-17.

[58] Morris, M. G., \& Venkatesh, V. (2010). Job Characteristics and Job Satisfaction: Understanding the Role of Enterprise Resource Planning System Implementation. MIS Quarterly, 34(1), 143-161. 
[59] Niraj, R., Gupta, M., \& Narasimhan, C. (2001). Customer Profitability in a Supply Chain. Journal of Marketing, 65(3), 1-16.

[60] Nkomo, S. M. (1987). Human Resource Planning and Organization Performance: An Exploratory Analysis. Strategic Management Journal, 8(4), 387-392.

[61] Plank, R. E., \& Reid, D. A. (1994). The Mediating Role of Sales Behaviors: An Alternative Perspective of Sales Performance and Effectiveness. The Journal of Personal Selling and Sales Management, 14(3), 43-56.

[62] Polonenko, D. R. (1999). Challenges and Issues in Scaling Commercial Production of Conifer Somatic Embryogenesis. In Vitro Cellular \& Developmental Biology. Plant, 35(4), 299-302.

[63] Ragowsky, A., \& Somers, T. M. (2002). Special Section: Enterprise Resource Planning. Journal of Management Information Systems, 19(1), 11-15.

[64] Ranganathan, C., Dhaliwal, J. S., \& Teo, T. S. H. (2004). Assimilation and Diffusion of Web Technologies in Supply-Chain Management: An Examination of Key Drivers and Performance Impacts. International Journal of Electronic Commerce, 9(1), 127 161.

[65] Rogers, D. S., \& Leuschner, R. (2004). Supply Chain Management: Retrospective and Prospective. Journal of Marketing Theory and Practice, 12(4), 60-65.

[66] Seawright, K. W., \& Young, S. T. (1996). A Quality Definition Continuum. Interfaces, 26(3), 107-113.

[67] Shen, Z., Dessouky, M., \& Ordonez, F. (2011). Perishable inventory management system with a minimum volume constraint. The Journal of the Operational Research Society, 62(12), 2063-2082.

[68] Smith, B. G. (2008). Developing Sustainable Food Supply Chains. Philosophical Transactions: Biological Sciences, 363(1492), 849861.

[69] Stadtler, H. (2005). Supply chain management and advanced planning - basics, overview and challenges. European Journal of Operational Research, 163(3), 575-588.

[70] Stenger, A. J. (2011). Advances in Information Technology Applications for Supply Chain Management. Transportation Journal, 50(1), 37-52. doi: 10.5325/transportationj.50.1.0037

[71] Stojanovi, x, \& Dragi. (1988). The Growth Matrix of the Sale. The Journal of the Operational Research Society, 39(11), 1051-1055. doi: $10.2307 / 2583205$

[72] Sun, D. (2004). Existence and Properties of Optimal Production and Inventory Policies. Mathematics of Operations Research, 29(4), 923-934.

[73] Sunder, S. (1976). Optimal Choice between FIFO and LIFO. Journal of Accounting Research, 14(2), 277-300. doi $10.2307 / 2490544$

[74] Swami, S., \& Shah, J. (2013). Channel coordination in green supply chain management. The Journal of the Operational Research Society, 64(3), 336-351.

[75] Swaminathan, J. M., \& Tayur, S. R. (2003). Models for Supply Chains in E-Business. Management Science, 49(10), 1387-1406.

[76] Sword, D. M., \& Cutsinger, J. (1984). Human Resource Planning and Budgeting: The Dallas Perspective. Public Administration Review, 44(2), 174-176. doi: 10.2307/975870

[77] Tuli, K. R., \& Bharadwaj, S. G. (2009). Customer Satisfaction and Stock Returns Risk. Journal of Marketing, 73(6), 184-197.

[78] Urban, T. L. (1992). An Inventory Model with an Inventory-LevelDependent Demand Rate and Relaxed Terminal Conditions. The Journal of the Operational Research Society, 43(7), 721-724. doi: $10.2307 / 2583581$

[79] Vokurka, R. J., \& Lummus, R. R. (1998). Balancing Marketing and Supply Chain Activities. Journal of Marketing Theory and Practice, 6(4), 41-50.

[80] Wagenheim, G. D., \& Reurink, J. H. (1991). Customer Service in Public Administration. Public Administration Review, 51(3), 263 270. doi: $10.2307 / 976950$

[81] Wang, E. T. G., Klein, G., \& Jiang, J. J. (2006). ERP Misfit: Country of Origin and Organizational Factors. Journal of Management Information Systems, 23(1), 263-292.

[82] Welch, C. E., \& Grover, P. L. (1991). An Overview of Quality Assurance. Medical Care, 29(8), AS8-AS28.

[83] Wolf, J. (2011). Sustainable Supply Chain Management Integration: A Qualitative Analysis of the German Manufacturing Industry. Journal of Business Ethics, 102(2), 221-235.

[84] Woodruff, D. L. (2004). [Supply Chain Management and Advanced Planning: Concept, Models, Software and Case Studies, Hartmut Stadtler, Christoph Kilger]. Interfaces, 34(2), 164-165.
[85] xe, \& zquez, A. (1995). A Note on the Arc Elasticity of Demand. Estudios Econ\&\#xf3;micos, $10(2$ (20)), 221-228.

[86] Yano, C. A., \& Rachamadugu, R. (1991). Sequencing to Minimize Work Overload in Assembly Lines with Product Options. Management Science, 37(5), 572-586.

[87] Zablah, A. R., Bellenger, D. N., \& Johnston, W. J. (2004). Customer Relationship Management Implementation Gaps. The Journal of Personal Selling and Sales Management, 24(4), 279-295.

[88] Zinszer, P. (1996). Supply Chain Strategies for Managing Excess Inventories. Journal of Marketing Theory and Practice, 4(2), 55-60.

Name - Rohit Vikas Akole

\section{Author Biography}

Email - akole.rohit50@gmail.com

Education - Ms in Technology Management, University of Bridgeport, CT, USA.

B.B.M.(E-commerce), North Maharashtra University, Jalgaon, $\mathrm{MH}$, India 